\title{
DETERMINATION OF CRITICAL PERIOD OF WEED COMPETITION AND EFFECT OF PLANT DISTRIBUTION PATTERNS ON WEEDS AND SESAME CROP (SESAMUM INDICUM L.) PRODUCTIVITY
}

\author{
EID, S. D. M.; A. A. TAHA and MAHA F. EL- ENANY \\ Weed Research Central Laboratory (WRCL), (ARC), Giza, Egypt.
}

(Manuscript received 7 May 2015)

\begin{abstract}
$\mathrm{F}$ our field experiments were conducted at Agricultural Research Station of Ismailia governorate, Agricultural Research Center, Egypt, in two studies during the two consecutive summer seasons of 2013 and 2014. First study (two experiments) was carried out to determine the critical period for weed control (CPWC) and its effect on weed infestation, sesame yield and its components. Each experiment included twelve treatments of weed removing after 3, 5, 7, 9 and 11 weeks and for the whole season; and weed interference with sesame plants for 3, 5, 7, 911 weeks and for the whole season. Second study (another two experiments) was done to evaluate the effect of planting distances (pd), planting distribution pattern and hand hoeing on weed infestation and on sesame yield and its component. The main findings of the first study was that the predicted CPWC in presence of mixed weed populations was found to expand from the $3^{\text {rd }}$ to $11^{\text {th }}$ weeks after planting (WAP). Existence of weed species infestation at fresh weight of 16.7 and 19.4 ton per faddan for whole seasons caused a highly significant reduction of sesame yields which estimated by $75.6 \%$ and $77.5 \%$ per faddan for first and second seasons respectively, compared to those obtained from weed free treatment for the whole seasons. The weed free for the whole season treatment, gave significant increase in plant height, length of fruiting zone, number of capsules per plant and total seed yield per faddan in both seasons. In the second study, planting distribution patterns at 10, 20 and 30 $\mathrm{cm}$ with seeding rate of 1,2 and 3 seeds per hill respectively, with respecting the recommended planting rate of 70000 plant per faddan revealed that planting of sesame at $10 \mathrm{~cm}$ and one seed per hill caused a significant reduction in number and fresh weight of weeds and has resulted in highest sesame plant height, number of capsules per plant and seeds yield per faddan in both seasons, compared to either of 20 or $30 \mathrm{~cm}$ distribution patterns, or to the weedy check in both seasons. These results demonstrated that planting distance at $10 \mathrm{~cm}$ with single plant per hill integrated with hand hoeing twice at 15 and 30 days after planting (DAP) are crucial for highest sesame yield production per faddan.
\end{abstract}

Nomenclature: Sesame, Sesamum indicum. 
Key words: Critical period of weed control, weed infestation, planting distance, plant distribution pattern, weed interference, Ismailia and Egypt.

\section{INTRODUCTION}

Sesame plant is considered as one of the most important oil crop worldwide. Its seeds are characterized by high unsaturated oil content up to $50 \%$, protein, calcium, iron and methionine and fatty acids, mineral salts and vitamins (Anonymous, 2006). In Egypt the total cultivated area is estimated to be 81000 Faddan that give 45000 tons of seeds (FAO Stat. 2012). Sesame plants is characterized by its slow seedling growth crop during initial growth stages which make it a poor competitor at earlier stages of crop growth Bennet et. al., (2003). Furthermore, losses caused by weeds were estimated to range between 49 and 70 percent due to the competition between sesame and weeds (Ghost and Mukhopdhyay 1980).

In previous studies, critical period of weed competition for sesame found to be between 15 to 45 days after plant sowing. (Beltrao 1997 and Amare et. al., 2009). Furthermore, works which done by Beltrao (1997) in Brazil showed variability in determined CPWC in Sausa and Monterio even with similar weed species due to site specific factors such as planting pattern and environmental conditions.

The Integrated Weed Management IWM involve a combination of cultural, mechanical, biological, genetic and chemical methods for effective and economical weed control (Swanton and Weise, 1991). In addition, IWM should provide the foundation for developing optimum weed control systems and efficient use of herbicides. Mahmoodi and Rahimi, (2009) stated that topography, climate, crop genetics and cultural practices such as tillage intensity, fertilization, seedling and row width are several factors that may influence the critical period for weed control (CPWC) by directly affecting weed composition, density, time of emergence relative to the crop or crop and weed growth. Kropff et. al., (1993) defined the critical period as the time interval between the maximum weed-infested period or the length of time that weeds which emerge with the crop can remain uncontrolled before they begin to compete with the crop and cause yield loss, and the minimum weed-free period or the length of time that the crop must be free of weeds after emergence for highest yield. Among different weed control methods, hoe weeding is the most used traditional method for weed control. However, this method is labour intensive and expensive and may cause mechanical damage to growing plant branches and roots (Adijun et. al., 2003) Therefore, determination of CPWC is an unaffordable approach to reduce high cost and uncertain labour availability for hoe -weeding especially in 
small scale areas. Accordingly, the present study was designed to determine CPWC for sesame plant and the effect of three planting patterns and hand hoeing treatment on weed infestation and sesame yield in the Agricultural Station at Ismailia, Egypt.

\section{MATERIALS AND METHODS}

Two studies were conducted through implementation of four field experiments in the successive years of $2013 / 14$, in a sandy soil (sand $89.6 \%$, silt $4.2 \%$ and clay $6.2 \% \mathrm{pH}$ 8.2) at Ismailia Research Station, Ismailia Governorate in 2013 and 2014 summer seasons. The un-branched sesame variety Shandaweel 3 was planted in field on 10 May 2013 in the first season and on 15 May 2014 in the second season. Plots consisted of 5 rows, $3.5 \mathrm{~m}$ long with $60 \mathrm{~cm}$ between rows. For respecting recommended seeds rate of 70 thousand per faddan regardless different planting distances, one, two and three sesame seeds were planted at planting distance (pd) of 10,20 and $30 \mathrm{~cm}$ between hills within rows, respectively. At soil preparation, 200 $\mathrm{kg} /$ faddan of superphosphate $\left(\mathrm{P}_{2} \mathrm{O}_{5} \quad 15.5 \%\right)$ were added. After one month, 50 $\mathrm{kg} /$ faddan of potassium sulphate $\left(48 \% \mathrm{~K}_{2} \mathrm{O}\right)$ were added. Two hundred $\mathrm{kg}$ of amonium nitrate $(33.5 \% \mathrm{~N})$ were divided into 5 equal doses were side dressed at $10,20,30,40$ and 50 days post-planting.

\section{First study in two experiments :}

\section{Determination of the critical period for weed competition (CPWC):}

For weed free periods, plots were kept free from weeds for 3, 5, 7,9,11 weeks and for whole season ( treatments no. 1-6) and after that weeds were allowed to compete with sesame plants for the remainder time of the season till harvest. In weed interference (competition) periods, normal weed populations were allowed to emerge and compete with sesame plants for 3,5,7,9,11 weeks and for the whole season (treatments no. 7-12) according to Dawson scheme (Dawson, 1977). Each treatment of the twelve was replicated 3 times in complete randomized block design.

\section{Data recorded at harvest time:}

1- Weed survey: Weeds were hand pulled from one square meter which randomly chosen in each plot and classified into species. Weed species were set in two categories as annual broad and narrow -leaf weed and their fresh weights were determined in $\mathrm{g} / \mathrm{m}^{2}$ and recorded.

2- Yield and its component at harvest time: Ten plants were taken randomly from each plot to determine the following yield component characters :

- Plant height from soil level to the top of canopy in $\mathrm{cm}$.

- First capsule height per plant in $\mathrm{cm}$. 
- Length of fruiting zone per plant in $\mathrm{cm}$.

- Number and weight of capsules per plant.

For yield, the whole plants of each plot were harvest and the following data were recorded:

- Seed yield in $\mathrm{Kg}$ per faddan.

- 1000 -seed index.

- Oil\% by Soxhlet apparatus.

\section{Second study in two experiments:}

\section{Estimation of plant distribution effect on weeds and magnitude of sesame yield losses:}

Each experiment included six treatments which were the combinations of three plant distance, hand hoeing (twice at 15 and 30 days post sowing) and no weed treatment (unweeding) in complete randomized block design as factorial design as follow:

1 - Planting distance at $10 \mathrm{~cm}$ between hills with one seed per hill (70000 plant /faddan) + hand hoeing.

2- Planting distance at $10 \mathrm{~cm}$ between hills with one seed per hill (70000 plant /faddan) + unweeding.

]3- Planting distance at $20 \mathrm{~cm}$ between hills with two seed per hill (70000 plant (faddan) + hand hoeing.

4- Planting distance at $20 \mathrm{~cm}$ between hills with two seed per hill (70000 plant /faddan) + unweeding.

5- Planting distance at $30 \mathrm{~cm}$ between hills with three seed per hill (70000 plant /faddan) + hand hoeing.

6- Planting distance at $30 \mathrm{~cm}$ between hills with three seed per hill (70000 plant /faddan) + unweeding.

\section{Data recorded :}

1- Weed survey at 60 days from sowing: Weeds were hand pulled from one square meter which chosen at random in each plot and classified into species. Weed species were set in two categories as annual broad leaf and narrow leaf weed and their fresh weights were determined in $\mathrm{g} / \mathrm{m}^{2}$.

2- Yield and its component at harvest time: Ten plants were taken randomly from each plot to determine the following yield component characters :

- Plant height from soil level to the top of canopy in $\mathrm{cm}$.

- First capsule height per plant in $\mathrm{cm}$.

- Length of fruiting zone per plant in $\mathrm{cm}$.

- Number and weight of capsules per plant. 
For yield, the whole plants of each plot were harvest and the following data were recorded:

- Seed yield in $\mathrm{Kg}$ per faddan.

- 1000 -seed index.

- Oil\% by Soxhlet apparatus.

\section{Statistical Analysis:}

All studied characters were analyzed statistically in complete randomized blocks design according to Snedecor and Cochran (1980) and LSD was estimated at 0.05 .

\section{RESULTS AND DISCUSSION}

\section{First study: Effect of weed removal and weed competition periods on weeds, sesame yield and its component:}

\section{1) On weeds:}

During the two growing summer seasons, there was dense natural weed infestation dominated by crow footgrass ( Dactyloctenium aegyptium L.), hairy carbgass ( Digitaria sanguinalis L.), common purslane (Portulaca oleracea L.) and common witch-grass (Panicum dichotomiflorum).

As shown in table (1), total fresh weight of narrow and broad-leaf weeds were estimated for both 2013 and 2014 seasons. In 2014, total weights of both weed groups were found to be higher than those in 2013. Furthermore, narrow-leaf weed species appeared to be more existent than broad leaf ones in both seasons. This observation may propose the need for more detailed studies on effect of inter specific competition among weed species especially that many researchers have focused on evaluating density-dependant interaction of a single weed species on certain crops with more investigated broad-leaf weeds than narrow-leaf weeds ( Zimdahl, 2004). For broad-leaf weed species, weed free treatments resulted in significant reduction of 95.35 and $94.04 \%$ in their weight in 2013 and 2014 respectively while for narrow-leaf weed species, a reduction of 90.72 and $94.04 \%$ in their fresh weight were obtained during 2013 and 2014, seasons respectively. For total weight of weeds, reductions were $92.79 \%$ and $90.33 \%$ for 2013 and 2014 seasons, respectively. On the other hand, weed competition treatment for the whole season has resulted in highly significant increase of total weight of weed species. These results are in line with Eagleton et. al., (1987) who stated that under weedy conditions, the weed biomass could reach six times that of sesame 48 days after planting DAP. Therefore, the suppression of weed growth at crop establishment is critical. 
Table 1. Effect of weed removal and weed competition periods on total weed infestation (fresh weight $\mathrm{g} / \mathrm{m}^{2}$ ) during 2013 and 2014 seasons.

\begin{tabular}{|c|c|c|c|c|c|c|}
\hline \multirow{3}{*}{$\begin{array}{c}\text { Weed removal or } \\
\text { competition (weeks) } \\
\text { Weed-free from sowing } \\
\text { for }\end{array}$} & \multicolumn{3}{|c|}{2013 season } & \multicolumn{3}{|c|}{2014 season } \\
\hline & \multicolumn{3}{|c|}{ Fresh weight of weeds in $\mathrm{g} / \mathrm{m}^{2}$} & \multicolumn{3}{|c|}{ Fresh weight of weeds in $\mathrm{g} / \mathrm{m}^{2}$} \\
\hline & $\begin{array}{l}\text { Broad- leaf } \\
\text { weeds }\end{array}$ & $\begin{array}{c}\text { Narrow- } \\
\text { leaf } \\
\text { weeds }\end{array}$ & $\begin{array}{c}\text { Total } \\
\text { weeds }\end{array}$ & $\begin{array}{c}\text { Broad- } \\
\text { leaf } \\
\text { weeds }\end{array}$ & $\begin{array}{c}\text { Narrow- } \\
\text { leaf } \\
\text { weeds }\end{array}$ & $\begin{array}{c}\text { Total } \\
\text { weeds }\end{array}$ \\
\hline 3 & 172.3 & 212.3 & 384.6 & 196.5 & 258.9 & 455.4 \\
\hline 5 & 141.7 & 164.3 & 306 & 159.8 & 188.2 & 348 \\
\hline 7 & 107 & 127.3 & 234.3 & 130.4 & 149.6 & 280 \\
\hline 9 & 75.3 & 97.7 & 173 & 91.5 & 116.3 & 207.8 \\
\hline 11 & 48.7 & 76.3 & 125 & 55.4 & 94.2 & 149.6 \\
\hline For the whole season & 8 & 19.7 & 27.7 & 11.7 & 32.3 & 44 \\
\hline \multicolumn{7}{|l|}{ Weed-competition for } \\
\hline 3 & 279 & 729 & 1008 & 286.8 & 771.4 & 1058.2 \\
\hline 5 & 452.3 & 1117.7 & 1570 & 485.6 & 1284.2 & 1769.8 \\
\hline 7 & 526.3 & 1460.3 & 1986.6 & 601.9 & 1574.6 & 2176.5 \\
\hline 9 & 655 & 1712.3 & 2367.3 & 742.5 & 1905 & 2647.5 \\
\hline 11 & 1004.3 & 2348 & 3352.3 & 1210.6 & 2593.4 & 3804 \\
\hline For the whole season & 1279 & 2765 & 4044 & 1645.3 & 2987.7 & 4630 \\
\hline LSD at 0.05 & 55.2 & 104.6 & 132.6 & 85.6 & 116.9 & 172.4 \\
\hline
\end{tabular}

\section{2) On sesame growth:}

As shown in table (2), plant height was significantly increased and gave highest value of 133.7 and $136.2 \mathrm{~cm}$ in 2013 and 2014 respectively compared to weed free treatment for the whole season. Contrary weed competition treatments gave a continuous decrease in plant height starting from the first 3 weeks to reach the shortest length of 83.3 and $88.7 \mathrm{~cm}$ in 2013 and 2014 respectively, at harvest, recording a reduction percentage of 37.6 and $34.87 \%$ in 2013 and 2014 respectively, than values obtained for weed free for the whole season.

Capsule length was found to be decreased periodically during weed free treatments to reach its maximum by harvest. However, same trait increased during weed competition to reach 54.5 and $58.3 \mathrm{~cm}$ by harvest compared to 40.1 and 42.4 $\mathrm{cm}$ in weed free treatments.

A gradual increase of fruiting zone was obtained to reach maximum of 93.6 and $93.8 \mathrm{~cm}$ by harvest during weed free treatments. However, weed interference during the first 3 weeks has resulted in highly significant decrease in length of fruiting zone compared to weed free period for the whole season by 69.23 and $67.69 \%$ for seasons 2013 and 2014 respectively.

As in the aforementioned component, maximum of capsule number per plant was obtained by the harvest in weed free treatment giving 74 and 76.5 capsule per 
plant by harvest. While during weed competition periods, gradual decrease in capsules' numbers were found to reach their highest reduction of 58.5 and $49.93 \%$ compared to weed free for the whole season in 2013 and 2014 seasons respectively. These differences in results obtained from weed free and weed competition could be due to less competition at less rates of weed infestation resulting in better effect on sesame yield in both seasons as explained by Imoloame, et. al., (2011). Contrary, all aforementioned plant characters were decreased along with extending of weed infestation period (weed competition). Furthermore, a significant reduction in number of capsule per plant was also started in both seasons at the third week after planting WAP among weed competition treatments. Higher values for $1^{\text {st }}$ capsule height were obtained with extending of weed competition for both seasons compared to those of weed free period. This could be understood as weed infestation affected normal performance of sesame plant leading to reduction of capsules' number per plant while low weed infestation under this treatment minimized weed competition for growth resources and allowed the sesame to take up enough moisture and nutrients for better growth Imoloame, et. al., (2011).

Table 2. Effect of weed removal and competition periods on sesame growth during the 2013 and 2014 seasons.

\begin{tabular}{|c|c|c|c|c|c|c|c|c|}
\hline \multirow[b]{2}{*}{$\begin{array}{c}\text { Weed removal } \\
\text { or competition } \\
\text { periods } \\
\text { (weeks) }\end{array}$} & \multicolumn{4}{|c|}{2013 season } & \multicolumn{4}{|c|}{2014 season } \\
\hline & $\begin{array}{l}\text { Plant } \\
\text { height. } \\
(\mathrm{cm})\end{array}$ & $\begin{array}{l}1^{\text {st }} \\
\text { capsule } \\
\text { height } \\
\text { in }(\mathrm{cm})\end{array}$ & $\begin{array}{l}\text { Length } \\
\text { of } \\
\text { fruiting } \\
\text { zone. } \\
(\mathrm{cm})\end{array}$ & $\begin{array}{c}\text { No of } \\
\text { capsules } \\
\text { / plant }\end{array}$ & $\begin{array}{l}\text { Plant } \\
\text { height. } \\
(\mathrm{cm})\end{array}$ & $\begin{array}{c}\text { Capsule } \\
\text { length } \\
\text {. (cm) }\end{array}$ & $\begin{array}{c}1^{\text {st }} \\
\text { capsule } \\
\text { height in } \\
\mathrm{cm}\end{array}$ & $\begin{array}{l}\text { Length } \\
\text { of } \\
\text { fruiting } \\
\text { zone. } \\
(\mathrm{cm})\end{array}$ \\
\hline $\begin{array}{l}\text { Weed-free } \\
\text { from sowing } \\
\text { for }\end{array}$ & & & & & & & & \\
\hline 3 & 113.6 & 61.9 & 51.7 & 58.6 & 115.2 & 52.2 & 63.2 & 59.9 \\
\hline 5 & 119.5 & 68.8 & 50.7 & 59.3 & 120.6 & 51.3 & 69.3 & 61.5 \\
\hline 7 & 121.1 & 71 & 50.1 & 61 & 123.3 & 50.7 & 72.6 & 62.4 \\
\hline 9 & 128 & 79.4 & 48.6 & 61.5 & 130.4 & 49.2 & 81.2 & 64 \\
\hline 11 & 129.3 & 80.9 & 48.4 & 67.9 & 131.7 & 48.8 & 82.9 & 69.9 \\
\hline $\begin{array}{l}\text { For the whole } \\
\text { season } \\
\text { Weed-infested } \\
\text { for }\end{array}$ & 133.7 & 93.6 & 40.1 & 74 & 136.2 & 42.4 & 93.8 & 76.5 \\
\hline 3 & 110.1 & 58.2 & 51.9 & 56.4 & 112.8 & 52.5 & 60.3 & 59.1 \\
\hline 5 & 106.5 & 53.9 & 52.6 & 39.3 & 108.3 & 53.2 & 55.1 & 44.6 \\
\hline 7 & 106.3 & 53.2 & 53.1 & 46.8 & 107.4 & 55.7 & 51.7 & 48.4 \\
\hline 9 & 102.4 & 48.4 & 54 & 40.8 & 101.1 & 57.2 & 43.9 & 46.2 \\
\hline 11 & 98.5 & 44.4 & 54.1 & 40.3 & 99.6 & 57.5 & 42.1 & 45.6 \\
\hline $\begin{array}{c}\text { For the whole } \\
\text { season }\end{array}$ & 83.3 & 28.8 & 54.5 & 30.7 & 88.7 & 58.3 & 30.3 & 38.3 \\
\hline LSD at 0.05 & 5.6 & 7.5 & 2.1 & 4.5 & 6.4 & 3.4 & 9.7 & 4.7 \\
\hline
\end{tabular}




\section{3) On sesame seed yield and its component:}

'Table (3) shows that weight of seeds per plant was gradually increased with the extending of the studied free periods to reach its significant higher values of 10.65 and $10.82 \mathrm{~g}$ of seeds per plant in both seasons respectively at weed free period for the whole season. However, values obtained from the first 3 weeks of weed competition caused 31.1 and $30.59 \%$ reduction reaching their higher reduction values of 56.8 and $52.77 \%$ in seeds' weight.

For weight of 1000 seed index, a gradual increase in values were noticed to reach highest significant values of 5.15 and $5.58 \mathrm{~g}$ at harvest in both seasons respectively. While no significant alteration in weight was obtained started from the first 3 weeks to harvest during weed competition periods reaching 34.36 and $38.70 \%$ reduction comparing to weed free period for the whole season for the two seasons respectively, suggesting the direct effect of weed interference on total weight of seeds since the first 3 weeks after planting in both seasons. Seed yield per faddan was significantly affected by weed competition periods started from the first treatment at the first 3 weeks in both seasons. In 2014, weed free treatment produced the highest sesame seed yield in general (465.8 kg/ faddan) compared to season 2013 (450.3 $\mathrm{kg} /$ faddan). While weed competition periods significantly caused lowest seed yield $(101 \mathrm{~kg})$ in 2013 and $(112.8 \mathrm{~kg})$ in 2014 recording reduction of 77.57 and $75.78 \%$ in total seed yield compared to weed free period for the whole season. In addition, loss in total yield resulted from the first 3 weeks of weed competition reached 40.77 and $41.06 \%$ for the two seasons respectively (table3). The obtained high seed yield and its component values could be attributed to less weed competition for growth resources leading to better growth and high yield of sesame. While, reduction in seed yield could be attributed to the fact that the initial growth of sesame is slow so weed interference causes reduction of the total yield. Furthermore, Amare, (2011) found that uninterrupted weed growth caused a reduction of $82.9 \%, 82.5 \%$ and $86.3 \%$ in yield, as compared to complete weed free in 2006, 2007 and 2008 seasons, respectively. In our results, an obvious decrease in total seed yields (about 59.2\%) started from the first 3 weeks of weed competition compared to complete weed free which gave $450.3 \mathrm{~kg} /$ Faddan in 2013 and $465.8 \mathrm{~kg} /$ Faddan in 2014. These results are not in agree with those of Ijlal et. al., (2011) that recorded only gradual decrease from 6.88 to $12.4 \%$ in seed yield from the $6^{\text {th }}$ weeks to full season weed crop 
competition while weed crop competition for a period of 3 weeks didn't show significant decrease in neither number of capsule per plant nor weight of 1000 seeds. This difference in the two results could be due to the difference in environmental locations and soil properties. Oil \% was not found to be significantly altered in any of weed free or weed competition periods treatments which could be explained as that weed competition as biotic stress could affect the plant physical and biological characters and not plant genetic potentialities tied with oil formation.

Table 3. Effect of weed competition periods on yield, yield component and oil \% of sesame crop during 2013 and 2014 seasons.

\begin{tabular}{|c|c|c|c|c|c|c|c|c|}
\hline \multirow[b]{2}{*}{$\begin{array}{c}\text { Weed removal or } \\
\text { competition periods } \\
\text { (weeks) }\end{array}$} & \multicolumn{4}{|c|}{2013 season } & \multicolumn{4}{|c|}{2014 season } \\
\hline & $\begin{array}{c}\text { Weight } \\
\text { of }\end{array}$ & $\begin{array}{c}\text { Weight } \\
\text { of }\end{array}$ & $\begin{array}{l}\text { Seed } \\
\text { yield }\end{array}$ & Oil \% & $\begin{array}{c}\text { Weight } \\
\text { of }\end{array}$ & $\begin{array}{c}\text { Weight } \\
\text { of }\end{array}$ & $\begin{array}{l}\text { Seed } \\
\text { yield }\end{array}$ & Oil \% \\
\hline $\begin{array}{c}\text { Weed-free from } \\
\text { sowing for }\end{array}$ & $\begin{array}{l}\text { Seeds in } \\
\mathrm{g} / \text { plant }\end{array}$ & $\begin{array}{l}1000 \\
\text { seeds } \\
\text { in } \mathrm{g}\end{array}$ & /faddan & & $\begin{array}{l}\text { Seeds in } \\
\mathrm{g} / \text { plant }\end{array}$ & $\begin{array}{c}1000 \text { in } \\
\mathrm{g} \\
\text { seeds }\end{array}$ & /faddan & \\
\hline 3 & 8.08 & 4.2 & 299.3 & 55.7 & 8.26 & 4.29 & 306.7 & 55.9 \\
\hline 5 & 8.5 & 4.28 & 307.3 & 55.6 & 8.84 & 4.4 & 335.4 & 55.7 \\
\hline 7 & 8.72 & 4.41 & 338.7 & 55.9 & 8.95 & 4.75 & 351.2 & 55.9 \\
\hline 9 & 9.04 & 4.67 & 363.3 & 55.3 & 9.31 & 4.82 & 386.5 & 55.5 \\
\hline 11 & 9.08 & 4.95 & 401 & 55.8 & 9.78 & 5.3 & 442.6 & 56 \\
\hline $\begin{array}{l}\text { For the whole season } \\
\text { Weed-infested for }\end{array}$ & 10.65 & 5.15 & 450.3 & 56.7 & 10.82 & 5.58 & 465.8 & 56.8 \\
\hline 3 & 7.33 & 3.82 & 266.7 & 55.8 & 7.51 & 4.03 & 274.5 & 56.2 \\
\hline 5 & 7.01 & 3.7 & 229 & 56 & 7.16 & 3.87 & 241.7 & 56.4 \\
\hline 7 & 6.38 & 3.66 & 206.7 & 55.5 & 6.55 & 3.73 & 215.2 & 55.7 \\
\hline 9 & 6.11 & 3.56 & 166 & 54.9 & 6.35 & 3.66 & 186.9 & 55.3 \\
\hline 11 & 4.9 & 3.5 & 148 & 55.2 & 5.28 & 3.58 & 160.4 & 55.4 \\
\hline For the whole season & 4.6 & 3.38 & 101 & 55.7 & 5.11 & 3.42 & 112.8 & 55.8 \\
\hline LSD at 0.05 & 1.08 & 0.79 & 20.6 & 1.7 & 1.32 & 0.84 & 25.7 & N.S. \\
\hline
\end{tabular}

\section{4) Determination of the critical period of weed competition for highest sesame yield:}

The critical period for weed control (CPWC) is identified as a period in the crop growth cycle during which weeds must be controlled (removed) to prevent yield losses Zimdahl (2004). Furthermore, for a given crop, CPWC can vary with the relative 
time of weed emergence and can be occurred from 0.00 to $35 \%$ of the growing season Knezevic et. al., (2002). In the present study, sesame yields were significantly reduced in both seasons if weeds were allowed to remain in the crop starting from the first 3 weeks giving a reduction in sesame seed yield $(\mathrm{kg} / \mathrm{faddan})$ in both seasons respectively until harvest (table 3 ). Therefore, the critical period for weed removing was estimated by biological curves for the relationship between weed free or weed competition periods and sesame seed yield per faddan and the aforementioned periods were found to be started during the first 3 weeks after planting and weed control must persist for at least $11^{\text {th }}$ WAP to obtain best reduction of weed competition and less seed yield loss (fig. 1). These results go in line with all agronomic crops where crops yield decreases with increasing time of weed interference for all weed species in several species-specific and mixed weed population studies (Zimdahl 2004). It also in accordance with finding of Amare et. al., (2009) that stated that CWCP in sesame lies between 10 to 30 days after sowing. In Egypt, Ijlal et. al., (2011) stated that weed density and dry weight did not increase significantly until CWCP was prolonged up to 3 and 4 weeks and growth decline was started after $3^{\text {rd }}$ week leading to significant yield decline at the $6^{\text {th }}$ week after crop emergence which is not going in line with our current results where, decline in the seed yield $(\mathrm{kg} /$ Faddan $)$ due to weed interference was noticed since the first 3 WAP. Findings of Beltrao (1997) in Brazil could be used to explain the difference in CWPC for sesame crop in Egypt where, a weed free period of 60 days after sesame emergence were considered crucial to prevent yield loss in Sausa whereas, 30-35 days after emergence is needed in the Monteiro, Brazil. He added that variability in the critical period of weed competition even with similar weed species is because of sitespecific factors such as planting pattern and environmental conditions. 


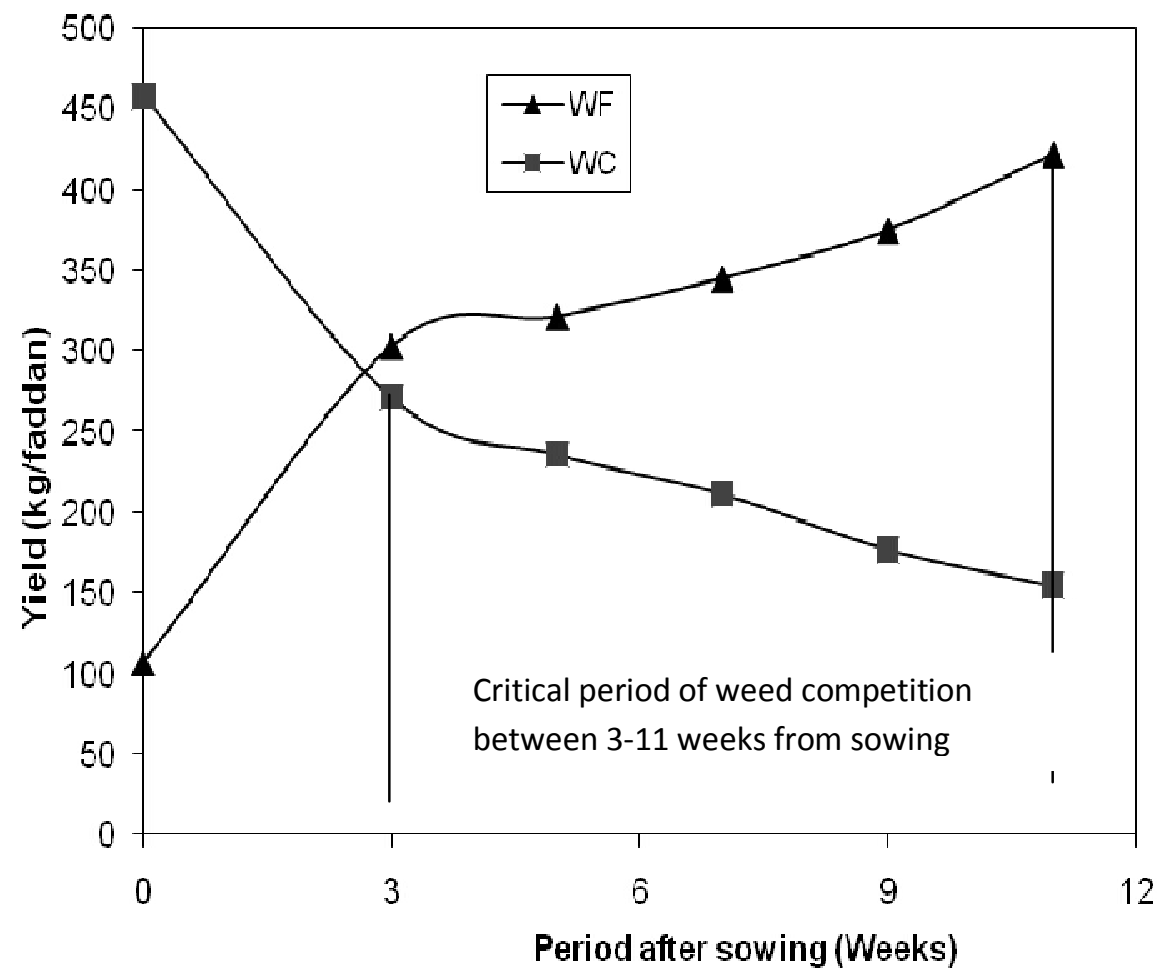

Fig. (1). Determination of critical period for weed competition in sesame fields using averaged sesame seed yields of 2013 and 2014 seasons. (WF) and (WC) denote weed free and weed interference (competition) for different length of time after planting respectively, to determine critical time for weed removing (CTWR) and critical weed free period (CWFP).

\section{Second study:}

Effect of plant distribution patterns and hoeing on weeds and sesame crop at early growth stages:

Sesame plants are known as slow growing crop with shallow canopy in early growing stages especially that weeds canopy in particular, quickly cover planted crop (Everman, et. al., 2008). In Egypt, certain farmers ignore recommendations issued by Ministry of Agriculture and Land Reclamation (MALR) and plant more than one sesame plant per hill to avoid unexpecting damages that might be caused by different sesame pests. Thus, planting at distance (pd) 10, 20 and $30 \mathrm{~cm}$ between hills and two hand hoeing were investigated and gave results shown below. 


\section{I- Effect of Plant distribution patterns:}

\section{1- On weed:}

Data in Table (4) clearly indicated that narrowing sesame sowing planting distances from 30 to $10 \mathrm{~cm}$ between hills caused significant reduction in both number and fresh weight of narrow and broad-leaf weeds and their total weight at $5 \%$ level of probability in 2013 and 2014 seasons. Reduction percentage in total number of weeds for both seasons were 44.37 and $27.84 \%$ for planting distance at 10 and $20 \mathrm{~cm}$ respectively compared to widest planting distance of $30 \mathrm{~cm}$ between hills $(437.73 \mathrm{~g}$ of weed per $\mathrm{m}^{2}$ for the two seasons). Mean of total fresh weight of weeds revealed a significant reduction by 35.12 and $21.16 \%$ for planting distance of 10 and $20 \mathrm{~cm}$ respectively compared to mean of values obtained from $30 \mathrm{~cm}$ pd for both seasons $\left(1963.08 \mathrm{~g} / \mathrm{m}^{2}\right)$. However, no significant variation between planting distance of 10 and $20 \mathrm{~cm}$ was observed. The depressing effect of narrowest pd $(10 \mathrm{~cm}$ with one plant per hill), could be resulted from over shading of sesame plants on weeds compared to other studied pds. Finally, it worth to mention that reduction \% in weeds' weight between narrow and broad-leaf weeds were increased in favor of narrow-leaf one along with increased planting distance.

Table 4. Effect of planting distance on weed infestation in sesame fields during season 2013 and 2014 seasons.

\begin{tabular}{|c|c|c|c|c|c|c|}
\hline \multirow{3}{*}{$\begin{array}{c}\text { Planting } \\
\text { Distribution pattern }(\mathrm{cm})\end{array}$} & \multicolumn{6}{|c|}{2013 season. } \\
\hline & \multicolumn{3}{|c|}{ No of weeds $\left(\mathrm{m}^{2}\right)$} & \multicolumn{3}{|c|}{ Fresh weight of weeds $\left(\mathrm{g} / \mathrm{m}^{2}\right)$} \\
\hline & $\begin{array}{c}\text { Broad- } \\
\text { leaf } \\
\text { weeds }\end{array}$ & $\begin{array}{l}\text { Narrow- } \\
\text { leaf weeds }\end{array}$ & Total & $\begin{array}{c}\text { Broad- } \\
\text { leaf } \\
\text { weeds }\end{array}$ & $\begin{array}{l}\text { Narrow- } \\
\text { leaf weeds }\end{array}$ & Total \\
\hline 10 (single plant / hill) & 43.0 & 188.7 & 231.7 & 453.5 & 755.2 & 1208.7 \\
\hline 20 (two plants / hill) & 73.0 & 232.5 & 305.5 & 533.7 & 946.3 & 1480.0 \\
\hline 30 (three plants / hill) & 90.0 & 328.8 & 418.8 & 633.5 & 1188.3 & 1821.8 \\
\hline LSD at 0.05 & 20.1 & 104.9 & 112.7 & 41.9 & 109.7 & 141.6 \\
\hline \multicolumn{7}{|c|}{2014 season. } \\
\hline 10 (single plant / hill) & 47.5 & 207.9 & 255.4 & 491.0 & 843.7 & 1334.7 \\
\hline 20 (two plants / hill) & 77.0 & 248.8 & 325.8 & 568.2 & 1040.4 & 1608.6 \\
\hline 30 (three plants / hill) & 103.5 & 352.8 & 456.3 & 706.2 & 1398.2 & 2104.3 \\
\hline LSD at 0.05 & 22.3 & 105.6 & 126.1 & 35.5 & 115.0 & 150.3 \\
\hline
\end{tabular}




\section{2- On sesame growth:}

In 2013, $10 \mathrm{~cm}$ pd didn't give significant values in plant height or length of the fruiting regions however, a significant increase in the first capsule height and number of capsules per plant was obtained. In 2014, a significant increase in plant height, first capsule height and number of capsule per plant were noticed. Meanwhile, no significant increase in length of fruit region was obtained (Table5). Surprisingly, this distance resulted in the shortest fruit region length in $\mathrm{cm}$.

Table 5. Effect of planting distance on sesame growth during 2013 and 2014 seasons.

\begin{tabular}{|c|c|c|c|c|}
\hline \multirow[b]{2}{*}{$\begin{array}{c}\text { Planting } \\
\text { Distribution pattern in }(\mathrm{cm})\end{array}$} & \multicolumn{4}{|c|}{2013 season. } \\
\hline & $\begin{array}{l}\text { Plant height } \\
\qquad(\mathrm{cm}) .\end{array}$ & $\begin{array}{c}1^{\text {st }} \text { capsule } \\
\text { height } \\
(\mathrm{cm}) .\end{array}$ & $\begin{array}{l}\text { Fruit region } \\
\text { length }(\mathrm{cm}) \text {. }\end{array}$ & $\begin{array}{c}\text { No of capsule } \\
\text { per plant }\end{array}$ \\
\hline 10 (single plant / hill) & 94.3 & 56.9 & 37.4 & 38.9 \\
\hline 20 (two plants / hill) & 91.6 & 46.3 & 45.3 & 34.2 \\
\hline 30 (three plants / hill) & 89.8 & 42.4 & 47.2 & 32.9 \\
\hline LSD at 0.05 & N.S & 8.6 & N.S & 3.1 \\
\hline \multicolumn{5}{|c|}{2014 season. } \\
\hline 10 (single plant / hill) & 96.9 & 58.2 & 38.7 & 42.1 \\
\hline 20 (two plants / hill) & 94.5 & 48.5 & 46.0 & 36.2 \\
\hline 30 (three plants /hill) & 91.7 & 42.9 & 48.9 & 34.0 \\
\hline LSD at 0.05 & 2.1 & 5.6 & N.S & 4.0 \\
\hline
\end{tabular}

\section{3- Sesame seed yield and its component and oil \%:}

As shown in table (6), although no significant increase in weight of seeds per plant or in weight of 1000 seed were obtained as a result of difference in planting distances in either seasons, a significant higher seeds yield (268.50 and 290.89 $\mathrm{kg} /$ faddan), were obtained in both seasons at plant distance of $10 \mathrm{~cm}$ with two hand hoeing, compared to 232.84 and $241.08 \mathrm{~kg} /$ faddan and 189.34 and $200.80 \mathrm{~kg} /$ faddan in both seasons at plant distance 20 and $30 \mathrm{~cm}$ respectively. Finally, no significant differences in oil \% were obtained in either of tested planting distance and hoeing or their interaction in both seasons (Table 6). The resulted decrease in total seed yield per faddan with pd of 20 and $30 \mathrm{~cm}$ compared to pd of $10 \mathrm{~cm}$ could be resulted from an intra-species competition for nutrition resources which could be also reflected on their capacity to shade and depress accompanied weed species growth.

The resulted high seeds yields in both seasons using planting distance of 10 $\mathrm{cm}$ compared to seed yield obtained from 20 and $30 \mathrm{~cm}$ planting distance as shown in 
table (5) and (6), could be due to early canopy closure which shaded off the weeds, depriving weeds from growth factors of sunlight, moisture and mineral nutrients as explained by Imoloame (2004), accordingly, planting distance of $10 \mathrm{~cm}$ could explain the augmentation in total seeds yields comparing to the other planting distance of 20 and $30 \mathrm{~cm}$ (table 5 and 6 ).

Table 6. Effect of planting distribution patterns on yield, yield component and oil \% of sesame seed crop for 2013 and 2014 seasons.

\begin{tabular}{|c|c|c|c|c|}
\hline \multirow{2}{*}{$\begin{array}{c}\text { Planting } \\
\text { Distribution pattern in }(\mathrm{cm})\end{array}$} & \multicolumn{4}{|c|}{2013 season } \\
\hline & $\begin{array}{l}\text { Seeds Weight } \\
\text { per plant }(\mathrm{g})\end{array}$ & $\begin{array}{c}\text { Weight of } \\
1000 \text { seed }(g)\end{array}$ & $\begin{array}{l}\text { Yield } \mathrm{Kg} / \\
\text { faddan }\end{array}$ & Oil \% \\
\hline 10 (single plant / hill) & 8.32 & 3.85 & 268.5 & 56.07 \\
\hline 20 (two plants / hill) & 7.57 & 3.62 & 232.8 & 55.44 \\
\hline 30 (three plants /hill) & 6.97 & 3.33 & 189.3 & 55.89 \\
\hline LSD at 0.05 & N.S & N.S & 42.10 & N.S \\
\hline \multicolumn{5}{|c|}{2014 season } \\
\hline 10 (single plant / hill) & 8.57 & 3.94 & 290.9 & 56.19 \\
\hline 20 (two plants / hill) & 7.63 & 3.65 & 241.1 & 55.52 \\
\hline 30 (three plants / hill) & 7.06 & 3.37 & 200.8 & 56.02 \\
\hline LSD at 0.05 & N.S & N.S & 45.6 & N.S \\
\hline
\end{tabular}

\section{II- Effect of weed control treatments:}

\section{1- On weeds:}

As shown in table (7), hand hoeing twice was found to be significantly affecting total number and weight of weeds in both seasons causing reduction in both weeds categories by 69.01 and $67.14 \%$ for number of weeds; and 71.5 and $71.29 \%$ for weight of weeds in 2013 and 2014 respectively.

Table 7. Effect of hoeing on weed infestation in sesame fields in seasons 2013 and 2014.

\begin{tabular}{|c|c|c|c|c|c|c|}
\hline \multirow{3}{*}{$\begin{array}{l}\text { Weeding } \\
\text { Method }\end{array}$} & \multicolumn{6}{|c|}{2013 season. } \\
\hline & \multicolumn{3}{|c|}{ No of weeds $\left(\mathrm{m}^{2}\right)$} & \multicolumn{3}{|c|}{ Fresh weight of weeds $\left(\mathrm{g} / \mathrm{m}^{2}\right)$} \\
\hline & $\begin{array}{c}\text { Broad- } \\
\text { leaf } \\
\text { weeds }\end{array}$ & $\begin{array}{c}\text { Narrow- } \\
\text { leaf } \\
\text { weeds }\end{array}$ & Total & $\begin{array}{c}\text { Broad- } \\
\text { leaf } \\
\text { weeds }\end{array}$ & $\begin{array}{l}\text { Narrow- } \\
\text { leaf weeds }\end{array}$ & Total \\
\hline Hoeing twice & 28.3 & 122.5 & 150.8 & 267.2 & 399.6 & 666.8 \\
\hline Untreated check & 109.0 & 377.6 & 486.6 & 813.2 & 1527.0 & 2340.2 \\
\hline LSD at 0.05 & 18.5 & 57.2 & 61.8 & 48.6 & 61.3 & 89.5 \\
\hline \multicolumn{7}{|c|}{2014 season. } \\
\hline Hoeing twice & 33.67 & 137.37 & 171.0 & 300.9 & 449.7 & 750.5 \\
\hline Untreated check & 118.33 & 402.23 & 520.6 & 876.0 & 1738.5 & 2614.5 \\
\hline LSD at 0.05 & 18.56 & 66.20 & 62.5 & 51.3 & 70.0 & 92.6 \\
\hline
\end{tabular}




\section{2- On sesame growth:}

As a result of hand hoeing, sesame growth was significantly increased compared to untreated check. As shown in table (8), plant height, $1^{\text {st }}$ capsule height, fruit region length and number of capsules per plants were affected.

Table 8. Effect of hand hoeing on sesame growth in 2013 and 2014 seasons

\begin{tabular}{|c|c|c|c|c|}
\hline \multirow[b]{2}{*}{$\begin{array}{l}\text { Weeding } \\
\text { Method }\end{array}$} & \multicolumn{4}{|c|}{2013 season. } \\
\hline & $\begin{array}{l}\text { Plant height } \\
\qquad(\mathrm{cm}) .\end{array}$ & $\begin{array}{c}\text { 1st capsule } \\
\text { height in (cm). }\end{array}$ & $\begin{array}{l}\text { Fruit region } \\
\text { length in } \\
\quad(\mathrm{cm}) .\end{array}$ & $\begin{array}{c}\text { No of capsule } \\
\text { per plant }\end{array}$ \\
\hline Hoeing twice & 111.96 & 56.13 & 55.82 & 53.33 \\
\hline Untreated check & 56.13 & 53.33 & 57.02 & 56.06 \\
\hline LSD at 0.05 & 6.2 & 2.67 & 5.7 & 3.71 \\
\hline \multicolumn{5}{|c|}{2014 season. } \\
\hline Hoeing twice & 113.64 & 57.02 & 56.62 & 56.06 \\
\hline Untreated check & 71.83 & 40.99 & 30.75 & 17.31 \\
\hline LSD at 0.05 & 7.12 & 3.43 & 6.1 & 3.92 \\
\hline
\end{tabular}

\section{3- On sesame yield and yield component:}

The effect of hand hoeing on yield, yield component and oil \% of sesame crop for 2013 and 2014 seasons were also investigated. Obtained results revealed that significant differences were observed for seeds weight per plant, weight of 1000 seed and seed yield in $\mathrm{kg}$ per faddan while variation in oil \% was not significant (table 9).

Table 9. Effect of hand hoeing on yield, yield component and oil \% of sesame crop for 2013 and 2014 seasons.

\begin{tabular}{|c|c|c|c|c|}
\hline \multirow[b]{2}{*}{$\begin{array}{l}\text { Weeding } \\
\text { Method }\end{array}$} & \multicolumn{4}{|c|}{2013 season. } \\
\hline & $\begin{array}{l}\text { Seed Weight } \\
\text { per plant }(\mathrm{g}) \text {. }\end{array}$ & $\begin{array}{c}\text { Weight of } \\
1000 \text { seed ( } \\
\text { g). }\end{array}$ & $\begin{array}{l}\text { Seed yield } \\
\mathrm{Kg} / \text { faddan }\end{array}$ & Oil \% \\
\hline Hoeing average & 10.39 & 3.94 & 361.44 & 56.28 \\
\hline Untreated average & 4.85 & 3.25 & 99.00 & 55.31 \\
\hline LSD at 0.05 & 0.87 & 0.09 & 16.60 & N.S \\
\hline \multicolumn{5}{|c|}{2014 season. } \\
\hline Hoeing average & 10.51 & 4.01 & 381.99 & 56.37 \\
\hline Untreated average & 4.99 & 3.29 & 106.52 & 55.45 \\
\hline LSD at 0.05 & 0.83 & 0.07 & 16.85 & N.S \\
\hline
\end{tabular}




\section{The effect of interactions between planting distribution patterns and weed control treatments:}

\section{On weeds:}

As shown in Table (10), the effect of interaction between planting distribution and hand hoeing on weed infestation was determined at $5 \%$ level. The interactions between the two studied factors were found to be not significant for number of narrow-leaf weeds, total number of weeds per meter square and fresh weight of broad-leaf weeds in 2013 season. Meanwhile, in 2014 season, the interaction between the two factors was found significant for both number and fresh weights of weeds for both narrow and broad-leaf weeds. These results indicate that narrowing of planting distance to $10 \mathrm{~cm}$ between hills reduce total fresh weight of weeds of both categories compared to planting distance of $30 \mathrm{~cm}$.

Table 10. Effect of interactions between planting distances and weed control treatments on weed infestation in seasons 2013 and 2014.

\begin{tabular}{|c|c|c|c|c|c|c|c|}
\hline \multirow{3}{*}{$\begin{array}{c}\text { Planting } \\
\text { Distribution } \\
\text { pattern } \\
(\mathrm{cm})\end{array}$} & \multirow[b]{3}{*}{$\begin{array}{l}\text { Weeding } \\
\text { Method }\end{array}$} & \multicolumn{6}{|c|}{2013 season. } \\
\hline & & \multicolumn{3}{|c|}{ No of weeds $\left(\mathrm{m}^{2}\right)$} & \multicolumn{3}{|c|}{ Fresh weight of weeds $\left(\mathrm{g} / \mathrm{m}^{2}\right)$} \\
\hline & & $\begin{array}{l}\text { Broad- } \\
\text { leaf } \\
\text { weeds }\end{array}$ & $\begin{array}{l}\text { Narrow- } \\
\text { leaf } \\
\text { weeds }\end{array}$ & Total & $\begin{array}{l}\text { Broad- } \\
\text { leaf } \\
\text { weeds }\end{array}$ & $\begin{array}{c}\text { Narrow-leaf } \\
\text { weeds }\end{array}$ & Total \\
\hline 10 (single & Hoeing & 16.0 & 83.7 & 99.7 & 206.0 & 282.0 & 488.0 \\
\hline plant / hill) & Untreated & 70.0 & 293.7 & 363.7 & 701.0 & 1228.3 & 1929.3 \\
\hline 20 (two & Hoeing & 27.0 & 124.9 & 151.7 & 260.3 & 381.0 & 641.3 \\
\hline plants/ hill) & Untreated & 119.0 & 340.3 & 459.3 & 807.0 & 1511.7 & 2318.7 \\
\hline 30 (three & Hoeing & 42.0 & 159.0 & 201.0 & 335.3 & 535.7 & 871.0 \\
\hline plants/hill) & Untreated & 138.0 & 498.7 & 636.7 & 931.7 & 1841.0 & 2772.7 \\
\hline LSD at 0.05 & & 14.7 & N.S & N.S & N.S & 106.1 & 155.1 \\
\hline \multicolumn{8}{|c|}{2014 season. } \\
\hline 10 (single & Hoeing & 18.0 & 91.5 & 109.5 & 220.0 & 331.4 & 551.4 \\
\hline plant / hill) & Untreated & 77.0 & 324.2 & 401.2 & 762.0 & 1356.0 & 2118.0 \\
\hline 20 (two & Hoeing & 31.0 & 146.0 & 177.0 & 288.3 & 405.6 & 693.9 \\
\hline plants/ hill) & Untreated & 123.0 & 351.5 & 474.5 & 848.0 & 1675.2 & 2523.2 \\
\hline 30 (three & Hoeing & 52.0 & 174.6 & 226.6 & 394.3 & 612.0 & 1006.3 \\
\hline plants/hill) & Untreated & 155.0 & 531.0 & 686.0 & 1018.0 & 2184.3 & 3202.3 \\
\hline LSD at 0.05 & & 15.5 & 49.4 & 75.1 & 59.3 & 83.3 & 112.5 \\
\hline
\end{tabular}




\section{On sesame plants' growth, yield, yield components and oil \% :}

Data presented in tables (11 and 12) showed that the interaction between planting distance and weed control treatments did not significantly affected sesame growth (table 11), or yield components (table 12). In addition, it worth to mention that the planting distance at $10 \mathrm{~cm}$ was also found to give highest values for plant height, $1^{\text {st }}$ capsule length, no. of capsules per plant, shortest fruit region and yield and its component, compared to pd of 20 and $30 \mathrm{~cm}$ respectively in both seasons.

Table 11. Effect of interaction between planting distances and weed control treatments on sesame growth for seasons 2013 and 2014. seasons.

\begin{tabular}{|c|c|c|c|c|c|}
\hline \multirow[b]{2}{*}{$\begin{array}{c}\text { Planting } \\
\text { Distribution pattern } \\
\text { in }(\mathrm{cm})\end{array}$} & \multirow[b]{2}{*}{$\begin{array}{l}\text { Weeding } \\
\text { Method } \\
\text { used }\end{array}$} & \multicolumn{4}{|c|}{2013 season. } \\
\hline & & $\begin{array}{l}\text { Plant height } \\
\text { (cm). }\end{array}$ & $\begin{array}{c}1 \text { st } \\
\text { capsule } \\
\text { height } \\
(\mathrm{cm}) .\end{array}$ & $\begin{array}{l}\text { Fruit } \\
\text { region } \\
\text { length in } \\
(\mathrm{cm}) \text {. }\end{array}$ & $\begin{array}{c}\text { No of capsule } \\
\text { per plant }\end{array}$ \\
\hline \multirow{2}{*}{10 (single plant / hill) } & Hoeing & 114.6 & 62.03 & 52.57 & 56.4 \\
\hline & Untreated & 74.07 & 51.83 & 22.24 & 21.4 \\
\hline \multirow{2}{*}{20 (two plants/ hill) } & Hoeing & 111.67 & 54.87 & 56.8 & 52.33 \\
\hline & Untreated & 71.47 & 37.77 & 33.7 & 16 \\
\hline \multirow{2}{*}{30 (three plants/hill) } & Hoeing & 109.6 & 51.5 & 58.1 & 51.27 \\
\hline & Untreated & 69.96 & 33.36 & 36.3 & 14.53 \\
\hline \multirow[t]{2}{*}{ LSD at 0.05} & & N.S & N.S & N.S & N.S \\
\hline & \multicolumn{5}{|c|}{2014 season. } \\
\hline \multirow{2}{*}{10 (single plant / hill) } & Hoeing & 116.38 & 63.25 & 53.13 & 61.64 \\
\hline & Untreated & 77.46 & 53.12 & 24.34 & 22.55 \\
\hline \multirow{2}{*}{20 (two plants/ hill) } & Hoeing & 113.85 & 57.36 & 56.49 & 53.88 \\
\hline & Untreated & 75.2 & 39.67 & 35.53 & 18.42 \\
\hline \multirow{2}{*}{30 (three plants/hill) } & Hoeing & 110.69 & 50.45 & 60.24 & 52.66 \\
\hline & Untreated & 72.75 & 35.24 & 37.51 & 15.35 \\
\hline LSD at 0.05 & & N.S & N.S & N.S & N.S \\
\hline
\end{tabular}


Table 12. Effect of interactions between planting distances and weed control treatment on yield, yield component and oil \% of sesame crop for 2013 and 2014 seasons.

\begin{tabular}{|c|c|c|c|c|c|}
\hline \multirow{4}{*}{$\begin{array}{l}\text { Planting } \\
\text { Distribution pattern } \\
\qquad(\mathrm{cm}) \\
10 \text { (single plant / hill) }\end{array}$} & \multirow[b]{2}{*}{$\begin{array}{c}\text { Weeding } \\
\text { Method } \\
\text { used }\end{array}$} & \multicolumn{4}{|c|}{2013 season. } \\
\hline & & $\begin{array}{c}\text { Seeds } \\
\text { Weight } \\
\text { per plant } \\
\text { ( } g) .\end{array}$ & $\begin{array}{c}\text { Weight of } \\
1000 \text { seed } \\
(\mathrm{g}) .\end{array}$ & $\begin{array}{c}\text { Yield } \\
\mathrm{Kg} / \text { faddan }\end{array}$ & Oil \% \\
\hline & Hoeing & 11.29 & 4.21 & 410.33 & 56.90 \\
\hline & Untreated & 5.34 & 3.48 & 126.67 & 55.23 \\
\hline & Hoeing & 10.34 & 3.95 & 369.00 & 55.77 \\
\hline & Untreated & 4.80 & 3.29 & 96.67 & 55.10 \\
\hline & Hoeing & 9.53 & 3.66 & 305.00 & 56.17 \\
\hline & Untreated & 4.41 & 2.99 & 73.67 & 55.60 \\
\hline LSD at 0.05 & & N.S & N.S & N.S & N.S \\
\hline \multicolumn{6}{|c|}{2014 season } \\
\hline \multirow{2}{*}{10 (single plant / hill) } & Hoeing & 11.46 & 4.35 & 446.32 & 57.05 \\
\hline & Untreated & 5.67 & 3.52 & 135.45 & 55.33 \\
\hline \multirow{2}{*}{20 (two plants/ hill) } & Hoeing & 10.41 & 3.98 & 377.50 & 55.80 \\
\hline & Untreated & 4.85 & 3.31 & 104.65 & 55.24 \\
\hline \multirow{2}{*}{30 (three plants/hill) } & Hoeing & 9.66 & 3.70 & 322.14 & 56.25 \\
\hline & Untreated & 4.46 & 3.03 & 79.46 & 55.79 \\
\hline LSD at 0.05 & & N.S & N.S & N.S & N.S \\
\hline
\end{tabular}

The effectiveness of hand hoeing was previously reported to be one of best control option in sesame fields that results in higher yields (Magani and Shave 2012). The aforementioned results indicate that applying of two hand hoeing could be enough for minimizing weed effects under Ismailia governorate conditions.

Finally, data deduced from this investigation reflects the high significant effects of weed interference on sesame crop since early plants emergence and the necessity of weed removal since the $3^{\text {rd }}$ WAP until the $11^{\text {th }}$ WAP under Ismailia Governorate conditions. Furthermore, it can be recommended that sesame plant distribution pattern of one plant per hill with total rate of 70000 plant per faddan, narrowing planting distance to $10 \mathrm{~cm}$ and hand hoeing twice at 15 and 30 DAP must be respected for effective weed control in sandy soil and to obtain highest seed yield of sesame per faddan under Ismailia Governorate conditions. 


\section{REFERENCES}

1. Adigun, J. A., and Lagoke, STO. 2003. Weed control in transplanted rainfed and imigated tomatoes in Nigeria Savanna, Niger. J. Weed Sci. 16: 24-30.

2. Amare, M. 2011. Estimation of critical period for weed control in sesame (Sesamum indicum L.) in northern Ethiop. Ethiop. J. Appl. Sci. Technol. 2 (1):5966.

3. Amare, M.; G. Woldewahid and J. J. Sharama 2009. Sesame crops versus weeds: when is the critical period of weed control? Proc. African Crop Sci. Conf. 9:591593.

4. Anonymous. 2006. Sesame: Past and future. SPORE (CTA), Netherland, 125:5-6.

5. Beltrao, N. E. 1997. Estimation of the competition period between weeds and sesame plant in the state of Paraiba. Comunicado -Tecnico-Centro-Nacional-de Pesquisa-de-Algodao 45:7.

6. Bennet, M.; Katherine and B. Code 2003. Sesame recommendations for the Northern Territory. Agnote 657(C22):1- 4.

7. Dawson, J.H. 1977. Competition of late-emerging weeds with sugar beets. Weed Sci. 25:168-170.

8. Eagleton, G.; S. Sandover and M. Dickson. 1987. Research Report: Sesame seed 1982-1986. Department of Agriculture, Kununurra, West Australia.

9. Everman, W. J., I. C. Burke, S. B. Clewis, W. E. Thomas, and J. W. Wilcut. 2008. Critical period of grass versus broad-leaf weed interference in peanut. Weed Technol. 22: 63-67.

10. Ghost, D. C and S. K. Mukhopdhyay. 1980. Weeds and weed control in sesame. Pesticides, 14 (11): 24-29.

11. Ijlal, Z.; A. Tanveer; M. E. Safdar; A. Aziz; M. Ashraf; N. Akhtar; F. A. Atif; A. Ali and M. M. Maqbool 2011. Effect of weed crop competition period on weeds and yield and yield components of sesame (Sesamum indicum L.) Pak. J. Weed Sci. Res. 17(1): 51-63.

12. Imoloame EO. 2004. Effects of seed rate and sowing method on weed infestation, growth and yield of sesame (Sesamum indicum L.) in the semi arid zone of Nigeria M.Sc. dissertation University of Maiduguri, p.48.

13. Imoloame, E. O.; S. D. Joshua and N. A. Gworgwor. 2011. Effect of preemergence herbicides on weed infestation and productivity of sesame (Sesamum indicum L.) in the Sudan Savanna Zone of Nigeria. J. Agric. Biotech. Sustainable Dev. 3 (2): 19-27. 
14. Lindquist. 2002. Critical period for weed control: The concept and data analysis. Weed Sci. 50: 773-786.

15. Kropff, M. J.; N. C. Vankeulen; H. H. VanLaar and B. J. Schenieders. 1993.The impact of the environmental and genetic factors. In: Kropff ،M.J and Van Laar, H.H. (Eds.). Modeling crop weed interactions. Wallingford, UK. CAB Inter. pp. 137-147.

16. Mahmoodi, S. and A. Rahimi. 2009. Estimation of critical period for weed control in corn in Iran. World Academy of Sci. Engineer. and Technol. 49: 67-72.

17. Magani, I. E and P. A. Shave. 2012. Effects of herbicide, seed rate and tillage systems on the yield of sesame (Sesamum indicum L.) At makurdi. Asian J. Exp. Biol. Sci. 3 (4): 688-693.

18. Snedecor, D.W. and Cochran, W. 1980. Statistical methods Seventhed, Iowa state University press, Iowa U.S.A.

19. Wilcut, J. W., A. C. York, and G. R. Wehtje. 1994. The control and interaction of weeds in peanut (Arachis hypogaea L.) Rev. Weed Sci. 6:177-205.

20. Zimdahl, R. L. 2004. Weed-crop competition: A review. Ames, IA: Blackwell publishing professional, $220 \mathrm{p}$. 


\title{
تقدير الفترة الحرجة لتنافس الحشائش وتأثير نمط التوزيع النباتى على الحشائش والإتتاج المحصولى لنبات السمسم
}

\author{
سعيد ضاحى محمد عيد أحمد عبد المنعم طه مها فهيم العنانى \\ الدعمل المركزي لبحوث الحشائش - مركز البحوث الزراعية - الجيزة.
}

تم إجر اء دراستين بواسطة تتفيذ أربعة تجارب حقلية بمحطة البحوث الزراعية التابعة

لمركز البحوث الزراعية بالاسماعيلية خلال عامي 2013 و2014. أجريت الدراسة الأولى لتقدير

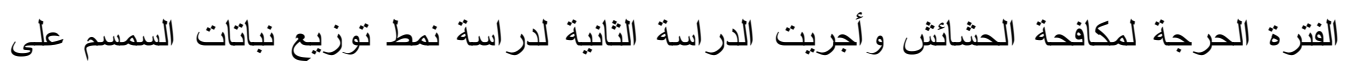

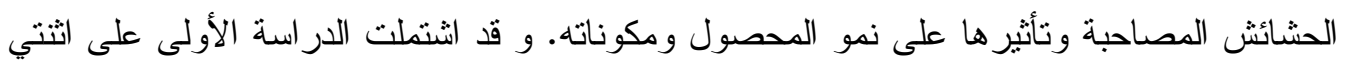

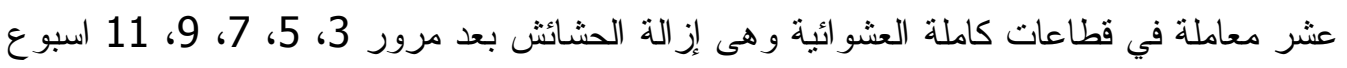

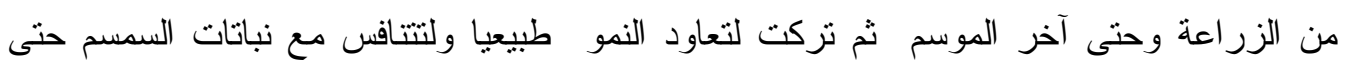

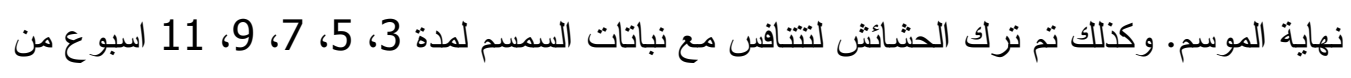
الزراعة وحتى آخر الموسم ـ أوضحت هذه الدراسة أن الفترة الحرجة لمكافحة الحشائش لتقليل

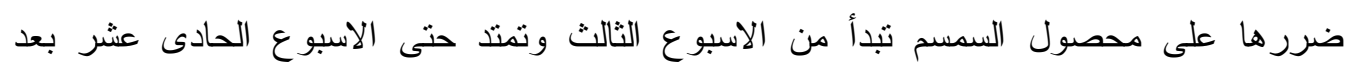

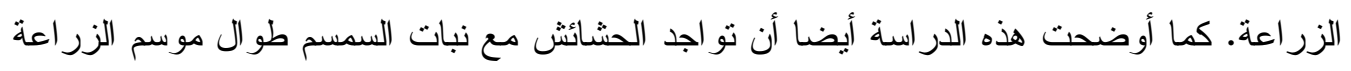
أدت الى انخفاض محصول السمسم بنسبة 75.76 و 77.5\% للفدان فى موسم الزر اعة 2013 و 2013 و

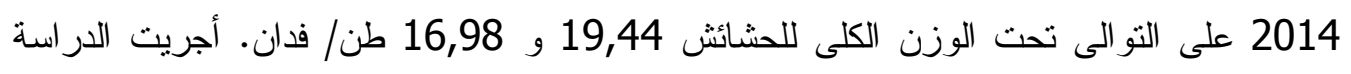
الثانية لدر اسة تأثير ثلاثة أنماط من التوزيع النباتى وهى (1) نبات واحد فى الجورة على مسافة 10

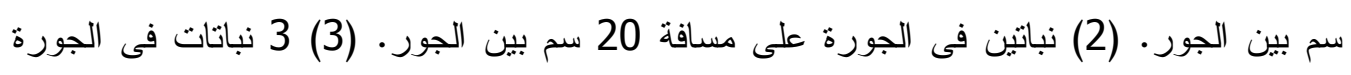

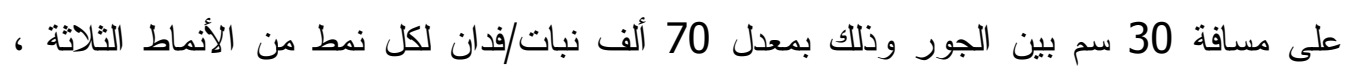

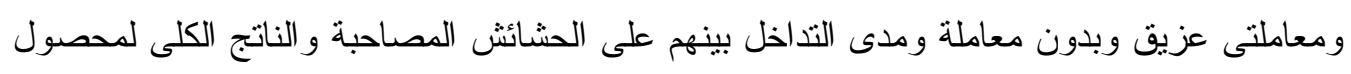

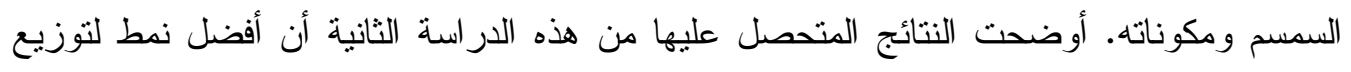
نباتات السمسم هو الزر اعة على مسافة 10 سم بين الجور مع نرك نبات واحد بالجورة بكثافة 70

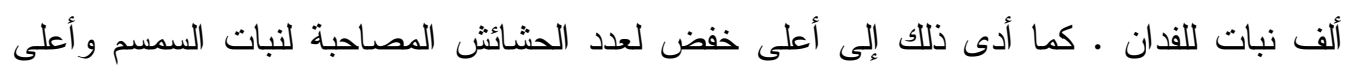
محصول بذرة مقارنة بالنمطين الأخرين بزر اعة نباتين فى الجورة على مسافة 20 سم بيت الجور

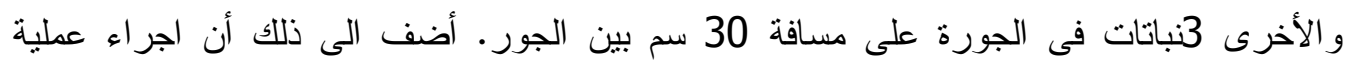

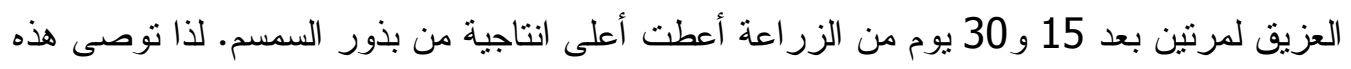

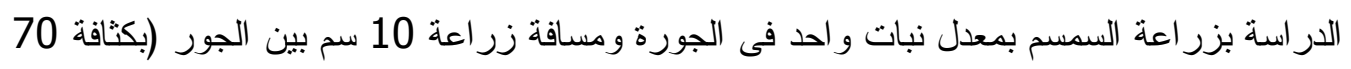

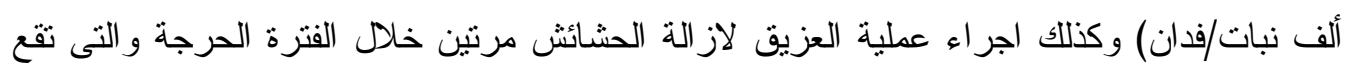
خلال الفترة من الأسبوع الثالث وحتى الأسبوع الحادى عثر للحصول على على أعلى كمية محصول بذرة من نبات السمسم فى الأراضى الرملية تحت ظروف محافظة الاسنة الاسماعيلية لجمهورية مصر العربية. 
